Herman T. Tavani:

\title{
Book Review: Honorary Volume for Evi Laskari
}

\author{
Honorary Volume for Evi Laskari. Edited by Maria Bottis (Athens, Greece: Nomiki Bibliothiki, 2013; xviii + 795 \\ pages. ISBN: 978-960-562-158-2).
}

Reviewed by Herman T. Tavani

Department of Philosophy, Rivier University (USA); htavani@rivier.edu

The Honorary Volume for Evi Laskari is a collection of short essays and full-length articles dedicated to the memory of Evi Laskari (1964-2008), philologist and former Head of the Central Public Library of Corfu (Greece). The volume is organized into two main sections or parts. Part I, titled "Texts on Evi Laskari," effectively serves as a (posthumous) festschrift for Laskari; it includes a series of short essays and texts that remark on her many contributions to the field of information/library science (in Corfu and beyond). Some essays in this section also hint at ways in which Laskari's work has influenced aspects of the field of information law/ethics, especially in the Greek academic community. (The eight short essays/texts that make up Part I are printed in both Greek and English.) Some of the essays included in this section also suggest ways in which Laskari's work might be interpreted as supporting the need for a dedicated forum in which scholars could meet at regular intervals to discuss ethical and legal issues affecting information/library science. In that regard, the annual ICIL (International Conference on Information Law/Ethics) Conference series, founded by Maria Bottis in 2008, has responded nicely to Laskari's legacy. Some thematic connections between the essays/texts included in Part I of this volume and the collection of full-length conference papers that follow in Part II will no doubt be recognized and appreciated by the discerning reader.

Part II is comprised of forty (selected) papers originally presented at the Fifth ICIL Conference (ICIL 2012) at the Ionian Academy, Corfu (June 29-30, 2012). This part of the volume is organized mainly into eight (topical) sections or chapters: 1 . Copyright; 2 . Patents; 3. Privacy; 4. Computer and Information Ethics; 5 . Freedom of Speech; 6. Libraries and Open Access; 7. Varia; and 8. Women in Academia. The length of the individual sections vary; for example, those on patents and libraries/open access contain only two papers each, while the sections on varia and copyright include eight and ten papers, respectively. What is particularly impressive about the papers comprising Part II is the diverse range of specific topics examined within the eight (general) sections or chapter headings. For example, papers included in the section/chapter on copyright examine copyrightrelated issues affecting particular nation states (such as Albania, Italy, the U.S., and the EU, in general), as well as copyright-specific controversies affecting different kinds of media, such as software (programming languages) and art (art-related Web sites). Unlike the papers in Part I, however, those included in Part II are printed only in English.

From this reviewer's perspective, four articles in Part II are particularly noteworthy: Migle Laukyte's "A Rawlsian Perspective on Copyright and Justice in Italy"; Richard Spinello and Sarah Cabral's "Rethinking Gene Patents"; Litska Strikwerda's "Should Virtual Cybercrime Be Brought under the Scope of the Criminal Law?" (included in the section/chapter on freedom of speech); and Paul Sturges' "The Brain at the Centre of the Universe: Lessons from Popular Neuroscience" (an ICIL 2012 keynote presentation). To comment in more detail on the content of some specific papers at the exclusion of others, however, might fail to do justice to the positive impact that the collection of papers in Part II will likely have, overall, for the readers of this volume. It is perhaps also worth noting that the closing section of Part II, "Woman in Academia," serves appropriately as a "bookend" to Part I; for example, the four papers comprising the final section, which examine a range of issues affecting gender in information/library science (in the Greek academic world) and information law/ethics (more broadly conceived), nicely complement the content in some of the short essays/texts dedicated to Evi Laskari in Part I. 
As already suggested, the Honorary Volume serves multiple functions - e.g., as a festschrift honoring Laskari, as well as a (hardcopy) proceedings for the ICIL 2012 conference papers. Moreover, it succeeds in accomplishing these disparate objectives quite effectively and coherently, via an overall theme (of information law/ethics) that unifies what might otherwise seem to be two distinct works warranting separate volumes. Some readers may note that this edited volume also has a Janus-like aspect in that it both "looks back" (on Laskari's life-long contributions to the field of information/library science) and "looks forward" via some timely papers (in Part II) that anticipate issues and controversies that will likely emerge in the field of information law/ethics in the near future.

Many readers will no doubt be struck by the manner in which this edited volume is so elegantly designed and presented (by its publisher, Nomiki Bibliothiki). I suspect that many readers will also be struck by the (overall) high quality of this volume's content, which was made possible in no small part by the impressive range of international scholars who contributed their papers to it. Not only does this handsome volume succeed in honoring Evi Laskari's legacy through its collection of essays/texts that pay homage to this worthy scholar, whose life's work has contributed significantly to the field of information/library science, but it has also cleverly provided a novel, or at least a slightly alternative, forum for disseminating print versions of papers originally presented at a major international conference. In an era when many conference proceedings now appear to be hastily assembled, sometimes with very little thought given to themes and organizing principles for arranging the content, and are then made available only online or only in digital media, Bottis's volume is a welcomed exception. Her volume should be applauded for bringing together quality conference papers and festschrift-like essays (which otherwise might never have been easily available to a broader international audience) in one, very-carefully-conceived book of readings. 